\title{
Pengaruh Kompensasi terhadap Kepuasan Kerja Pegawai Bagian SDM \& Umum PT KAI Daerah Operasi 1 Jakarta
}

\author{
Gappuraning Rahayu', Eigis Yani Pramularso ${ }^{2}$ \\ ${ }^{1}$ Universitas Bina Sarana Informatika \\ e-mail: gappuraningrahayu@gmail.com \\ ${ }^{2}$ Universitas Bina Sarana Informatika \\ e-mail: eigis.eyp@bsi.ac.id
}

\begin{abstract}
Compensation is one of the important parts in an effort to meet job satisfaction for employees in an organization. With high job satisfaction employees are expected to feel happy at work, more motivated in work, increased productivity, and make employees become more loyal to the organization. This study aims to determine the effect of compensation on employee job satisfaction at PT Kereta Api Indonesia (Persero) Operational Area 1 Jakarta. The study was conducted by dividing the questionnaire to a number of 35 people, all employees of the general section and HR who were used as research samples. Data analysis using simple regression analysis, correlation coefficient, and coefficient of determination. The results of the study indicate a positive and direct effect between compensation for employee job satisfaction. Based on the calculation of the correlation coefficient obtained a result of 0.723 where the number of scores shows the strong relationship of compensation to employee job satisfaction. From the calculation of the coefficient of determination, it can be seen that compensation affects employee job satisfaction by $52.3 \%$ while the remaining $47.7 \%$ is influenced by other factors beyond research.
\end{abstract}

Key Word: Financial compensation, non financial compensation, Job Satisfaction

\section{I.PENDAHULUAN}

Sumber daya manusia menjadi salah satu sumber daya yang sangat penting untuk memperoleh perhatian dan terus ditingkatkan perannya dalam organisasi manusia. Salah satu upaya yang dapat diberikan organisasi dengan memberi perhatian terhadap kompensasi yang diberikan kepada bagi pegawainya. Bagi pegawai, kompensasi menjadi harapan dan hak yang sepantasnya diterima sebagai balas jasa atas kontribusinya terhadap organisasi selama bekerja.

Kompensasi perlu menjadi perhatian penting bagi organisasi. Organisasi semestinya memberikan kompensasi yang layak dan adil sehingga pegawai terus merasa puas dan terdorong untuk melakukan pekerjaan dengan lebih baik. Kompensasi juga menjadi upaya organisasi dalam mempertahankan sumber daya manusia yang dimilikinya karena menyadari bahwa pegawai berkualitas adalah aset berharga dalam menentukan keberhasilan organisasi dalam mencapai tujuannya.

Kepuasan kerja bagi pegawai merupakan hal yang bersifat individu. Setiap pegawai memiliki tingkat kepuasan kerja yang berbeda-beda sesuai penilaian diri masing-masing. Kepuasan kerja yang baik dapat ditunjukkan dengan adanya pegawai merasa senang dalam melaksanakan pekerjaannya, terus meningkatkan produktivitasnya, semakin termotivasi dalam berprestasi, dan loyal kepada organisasi.
Pemberian kompensasi menjadi salah satu yang dapat diupayakan terkait dengan kepuasan kerja. Puas atau tidak puasnya pegawai terhadap kompensasi yang diterima memiliki pengaruh terhadap hasil pekerjaan yang dilakukannya. Untuk itu, kompensasi menjadi salah satu bagian kebijakan organisasi yang harus terus diperhatikan sungguh-sungguh dengan memberikan kompensasi yang sesuai dan layak sehingga terpenuhi kepuasan kerja pada diri setiap pegawai. Menurut Mangkunegara dalam (Retnoningsih, Sunuharjo, \& Ruhana, 2016) kompensasi yang diberikan kepada pegawai sangat berpengaruh pada tingkat kepuasan kerja dan motivasi kerja, serta hasil kerja.

Hasibuan dalam (Akmal \& Tamini, 2015) mengemukakan tujuan pemberian kompensasi adalah sebagai ikatan kerja sama, kepuasan kerja, pengadaan efektif, motivasi, stabilitas karyawan, disiplin, pengaruh serikat buruh. dan pengaruh pemerintah.

Menurut (Hartatik, 2014) kompensasi mencakup balas jasa finansial dan nonfinansial. Kompensasi merupakan pemberian balas jasa, baik secara langsung berupa uang (finansial) maupun secara tidak langsung berupa penghargaan (non finansial). Menurut (Mulyadi, 2015) kompensasi adalah setiap bentuk yang diberikan kepada seluruh karyawan sebagai balas jasa atas konstribusi yang diberikan kepada perusahaan/organisasi. Menurut Mangkunegara dalam (Chintya, 2018) kompensasi 
merupakan sesuatu yang dipertimbangkan sebagai sesuatu yang sebanding.

Menurut Leon C. Megginson dalam (Mangkunegara, 2015) faktor-faktor yang mempengaruhi kompensasi adalah faktor pemerintah., penawaran bersama antara perusahaan dan pegawai, biaya hidup pegawai, ukuran perbandingan upah, permintaan dan persediaan, dan kemampuan membayar.

Menurut Rivai dalam (Hartatik, 2014) jenis-jenis kompensasi terbagi menjadi dua, yaitu:

1. Kompensasi Finansial

Kompensasi finansial terdiri atas dua jenis yaitu kompensasi langsung dan kompensasi tidak langsung. Bentuk kompensasi langsung berupa pembayaran pokok (gaji/upah), prestasi, insentif, komisi, bonus, bagian keuangan, opsi saham dan pembayaran tertangguh (tabungan hari tua). Kompensasi tidak langsung terdiri atas proteksi yang meliputi asuransi, pesangon, sekolah anak, pensiun; kompensasi luar jam kerja meliputi lembur, hari besar, cuti sakit, dan cuti hamil; dan kompensasi berdasarkan fasilitas meliputi rumah, biaya pindah, dan kendaraan.

2. Kompensasi Non Finansial

Kompensasi non finansial biasanya dikarenakan karir, yang meliputi peluang promosi, pengakuan karya, teman baru, prestasi istimewa. Sedangkan kompensasi dikarenakan lingkungan kerja meliputi mendapat pujian, bersahabat, nyaman bertugas, menyenangkan dan kondusif.

Menurut Hasibuan dalam (Hartatik, 2014) kepuasan kerja adalah sikap emosional yang menyenangi dan mencintai pekerjaannya. Robbins dalam (Subariyanti, 2017) mendefinisikan kepuasan kerja sebagai sikap secara umum dan tingkat perasaan positif seseorang terhadap pekerjaannya. Sedangkan menurut Handoko dalam (Safrudi, 2015) kepuasan kerja (Job satisfaction) adalah keadaan emosional yang menyenangkan atau tidak menyenangkan dengan para karyawan memandang pekerjaan mereka.

Menurut Sa'ad dalam (Priansa, 2017) mengemukakan bahwa faktor-faktor yang mempengaruhi kepuasan kerja yaitu sebagai berikut:

1. Faktor psikologi, yaitu faktor yang berkaitan dengan kewajiban pegawai, meliputi minat, kenyamanan dalam bekerja, sikap terhadap pekerjaan, bakat, serta keterampilan yang dimiliki.

2. Faktor sosial, faktor yang berkaitan dengan interaksi sosial, baik antara sesama pegawai, atasannya, maupun pegawai yang berbeda jenis pekerjaannya.

3. Faktor fisik, yaitu faktor yang berkaitan dengan kondisi fisik lingkungan kerja dan kondisi fisik pegawai.
4. Faktor finansial, yaitu faktor yang berhubungan dengan jaminan serta kesejahteraan pegawai, yaitu meliputi sistem dan besarnya gaji atau upah, jaminan sosial, macam-macam tunjangan, fasilitas yang diberikan, promosi dan sebagainya.

Menurut Robbins dalam (Badriyah, 2015) ada beberapa aspek yg dapat mempengaruhi kepuasan kerja karyawan, yaitu:

1. Pekerjaan yang menantang.

2. Ganjaran yang pantas.

3. Kondisi kerja yang mendukung.

4. Rekan kerja yang mendukung..

5. Kesesuaian kepribadian dengan pekerjaan.

Penelitian oleh (Akmal \& Tamini, 2015) menunjukan bahwa menunjukkan adanya pengaruh kompensasi yaitu upah pokok dan insentif terhadap kepuasan kerja karyawan Gayamakmur Mobil Medan. Penelitian oleh (Purnamasari, 2013) menunjukkan ada pengaruh antara kompensasi terhadap kepuasan kerja pegawai pada PT. Eliza Parahyangan Sub Cabang Garut dengan. Penelitian oleh (Retnoningsih et al., 2016) menunjukkan bahwa variabel kompensasi finansial berpengaruh terhadap kepuasan kerja karyawan dan kompensasi non finansial berpengaruh terhadap kepuasan kerja karyawan PT PLN (Persero) Distribusi Jawa Timur Area Malang.

\section{METODOLOGI PENELITIAN}

Pengumpulan data dalam penelitian ini dengan menggunakan beberapa metode, yaitu:

1. Metode Observasi

Melakukan pengamatan dengan datang langsung ke kantor PT Kereta Api Indonesia (Persero) Daerah Operasi 1 Jakarta untuk mendapatkan informasi yang dibutuhkan.

2. Metode Kuesioner

Mengajukan daftar pertanyaan tertutup kepada pegawai bagian SDM \& Umum PT Kereta Api Indonesia (Persero) Daerah Operasi 1 Jakarta yang merupakan responden pada penelitian ini.

3. Dokumentasi

Mengumpulkan data yang berasal dari beberapa buku referensi yang berkaitan penelitian ini.

Populasi menurut (Sugiyono, 2016) adalah wilayah generalisasi yang terdiri atas obyek/subyek yang mempunyai kualitas dan karakteristik tertentu yang ditetapkan oleh peneliti untuk dipelajari dan kemudian ditarik kesimpulan. Populasi dalam penelitian ini adalah pegawai pada PT Kereta Api Indonesia (Persero) Daerah Operasi 1 Jakarta bagian SDM \& Umum sebanyak 35 orang yang berkantor di Jl. Pegangsaan Timur No. 6, Pegangsaan Menteng, Jakarta Pusat 10330.

Menurut (Sugiyono, 2016) sampel adalah bagian dari jumlah dan karakteristik yang dimiliki oleh populasi tersebut. Sampel jenuh adalah teknik penentuan sampel bila semua anggota populasi dijadikan 
sampel. Hal ini sering dilakukan bila jumlah populasi relatif kecil, kurang dari 30 orang atau digunakan apabila ingin melakukan penelitian yang general dengan kesalahan yang sangat kecil (Sugiyono, 2016). Teknik pengambilan sampel dalam penelitian ini menggunakan sampling jenuh atau sensus karena semua pegawai pada PT Kereta Api Indonesia (Persero) Daerah Operasi 1 Jakarta bagian SDM \& Umum yang berjumlah 35 orang dijadikan sampel. Peneliti menggunakan sampel jenuh karena populasi relatif kecil dan ingin melakukan penelitian secara general dengan kesalahan yang sangat kecil.

Uji instrumen penelitian yang digunakan dalam penelitian ini, sebagai berikut:

1. Uji Validitas

(Sujarweni, 2015) menjelaskan bahwa uji validitas digunakan untuk mengetahui kelayakan butir-butir dalam suatu daftar pertanyaan dalam mendefinisikan suatu variabel. Hasil $r$ hitung kita bandingkan dengan $\mathrm{r}$ tabel dimana $\mathrm{df}=\mathrm{n}-2$ dengan sig 5\% dan jika $r$ tabel < $r$ hitung maka valid (Sujarweni, 2015) .

2. Uji Reliabilitas

(Sujarweni, 2015) menjelaskan bahwa reliabilitas (keandalan) merupakan ukuran suatu kestabilan dan konsistensi dalam menjawab hal yang berkaitan dengan kontruk-kontruk pertanyaan yang merupakan dimensi suatu variabel dan disusun dalam suatu bentuk kuesioner.

Tabel 1. Skala Alpha Cronbach's

\begin{tabular}{cc}
\hline Nilai Alpha & Keterangan \\
\hline $0,0-0,20$ & Kurang Reliabel \\
\hline $0,21-0,40$ & Agak Reliabel \\
\hline $0,41-0,60$ & Cukup Reliabel \\
\hline $0,61-0,80$ & Reliabel \\
\hline $0,81-1,00$ & Sangat Reliabel \\
\hline
\end{tabular}

Sumber: (Sujarweni, 2015)

Analisis data dalam penelitian ini menggunakan menggunakan analisis regresi sederhana, koefisien korelasi, dan koefisien determinasi. Untuk pengolahan data menggunakan bantuan SPSS versi 22. Menurut (Sugiyono, 2016) uji koefisien kolerasi adalah teknik yang digunakan untuk mencari hubungan dan membuktikan hipotesis hubungan dua variabel berbentuk interval dan dari sumber data yang sama.

Menurut (Sugiyono, 2016) rumus koefisien regresi dapat digunakan untuk melakukan prediksi seberapa tinggi nilai variabel dependen bila nilai variabel independen dimanipulasi (dirubah-ubah). Untuk persamaan regresi dirumuskan sebagai berikut:

Rumus:

$Y=a+b x$

Keterangan:

$\mathrm{Y}=$ =Nilai yang diprediksikan (variabel terikat)

a $=$ Konstanta atau bila harga $\mathrm{X}=0$ $\mathrm{b}=$ Koefisien regresi, yaitu peningatan atau penurunan variabel $\mathrm{Y}$ yang didasarkan pada variabel $\mathrm{X}$

$\mathrm{X}=$ Nilai variabel independen (variabel bebas)

Tabel 2. Pedoman Untuk Memberikan Interpretasi Koefisien Korelasi

\begin{tabular}{cc}
\hline Interval Koefisien & Tingkat Hubungan \\
\hline $0,00-0,19$ & Sangat Rendah \\
\hline $0,20-0,399$ & Rendah \\
\hline $0,40-0,599$ & Sedang \\
\hline $0,60-0,799$ & Kuat \\
\hline $0,80-1,000$ & Sangat Kuat \\
\hline
\end{tabular}

Sumber: (Sugiyono, 2016)

\section{HASIL DAN PEMBAHASAN}

3.1. Uji Validitas dan Uji Reliabilitas

Dengan menggunakan program komputer SPSS hasil uji perhitungan validitas variabel kompensasi (X) dapat dilihat pada tabel 3 sebagai berikut:

Tabel 3. Uji Validitas Variabel Kompensasi

\begin{tabular}{ccccc}
\hline $\begin{array}{c}\text { Varia } \\
\text { bel }\end{array}$ & $\begin{array}{c}\text { Indika } \\
\text { tor }\end{array}$ & $\begin{array}{c}\mathbf{r} \\
\text { hitung }\end{array}$ & $\begin{array}{c}\mathbf{r} \\
\text { tabel }\end{array}$ & $\begin{array}{c}\text { Ketera } \\
\text { ngan }\end{array}$ \\
\hline & $\mathrm{X} 1$ & 0,484 & 0,334 & Valid \\
\cline { 2 - 5 } & $\mathrm{X} 2$ & 0,451 & 0,334 & Valid \\
\cline { 2 - 5 } & $\mathrm{X} 3$ & 0,745 & 0,334 & Valid \\
\cline { 2 - 5 } $\begin{array}{c}\text { Kom } \\
\text { pensasi } \\
(\mathrm{X})\end{array}$ & $\mathrm{X} 4$ & 0,503 & 0,334 & Valid \\
\cline { 2 - 5 } & $\mathrm{X} 5$ & 0,569 & 0,334 & Valid \\
\cline { 2 - 5 } & $\mathrm{X} 7$ & 0,794 & 0,334 & Valid \\
\cline { 2 - 5 } & $\mathrm{X} 8$ & 0,714 & 0,334 & Valid \\
\cline { 2 - 5 } & $\mathrm{X} 9$ & 0,820 & 0,334 & Valid \\
\hline
\end{tabular}

Sumber: Data SPSS yang diolah, 2018.

Berdasarkan tabel $\mathrm{r}$ uji 2 (dua) arah dengan $\mathrm{N}=$ $35 / \mathrm{df}=33$ taraf kesalahan $5 \%$ diperoleh nilali $\mathrm{r}$ tabel 0,334 . Adapun output yang dihasilkan berdasar pada tabel 3 untuk semua item pernyataan untuk kompensasi $(\mathrm{X})$ adalah valid karena > 0,334. Maka dapat disimpulkan bahwa indikator kompensasi tersebut dapat dipergunakan untuk penelitian.

Hasil uji perhitungan validitas variabel kepuasan kerja (Y) dapat dilihat pada tabel 4 dibawah ini:

Tabel 4. Uji Validitas Variabel Kepuasan Kerja

\begin{tabular}{ccccc}
\hline $\begin{array}{c}\text { Varia } \\
\text { bel }\end{array}$ & $\begin{array}{c}\text { Indikat } \\
\text { or }\end{array}$ & $\begin{array}{c}\text { r } \\
\text { hitung }\end{array}$ & $\begin{array}{c}\text { r } \\
\text { tabel }\end{array}$ & $\begin{array}{c}\text { Ketera } \\
\text { ngan }\end{array}$ \\
\hline & Y1 & 0,701 & 0,334 & Valid \\
\cline { 2 - 5 } & Y2 & 0,786 & 0,334 & Valid \\
\cline { 2 - 5 } & Y3 & 0,791 & 0,334 & Valid \\
\cline { 2 - 5 } & Y4 & 0,553 & 0,334 & Valid \\
\cline { 2 - 5 } Kepuasan & Y5 & 0,678 & 0,334 & Valid \\
\cline { 2 - 5 } Kerja (Y) & Y6 & 0,832 & 0,334 & Valid \\
\cline { 2 - 5 } & Y7 & 0,750 & 0,334 & Valid \\
\cline { 2 - 5 } & Y8 & 0,386 & 0,334 & Valid \\
\cline { 2 - 5 } & Y9 & 0,817 & 0,334 & Valid \\
\cline { 2 - 5 } & Y10 & 0,729 & 0,334 & Valid \\
\hline
\end{tabular}

Sumber: Data SPSS yang diolah, 2018. 
Berdasarkan tabel $\mathrm{r}$ uji 2 (dua) arah dengan $\mathrm{N}=$ $35 / \mathrm{df}=33$ taraf kesalahan 5\% diperoleh nilali $\mathrm{r}$ tabel 0,334 . Adapun output yang dihasilkan berdasar pada tabel 4 untuk semua item kepuasan kerja (Y) adalah valid karena > 0,334. Maka dapat disimpulkan bahwa indikator kepuasan kerja tersebut dapat dipergunakan untuk penelitian.

Hasil uji reliabilitas variabel kompensasi (X) dapat dijelaskan pada tabel 5 sebagai berikut:

Tabel 5. Reliabilitas Variabel Kompensasi

\begin{tabular}{cc}
\hline \multicolumn{2}{c}{ Reliability Statistics } \\
\hline Cronbach's Alpha & N of Items \\
\hline 0,868 & 10 \\
\hline
\end{tabular}

Sumber: Data SPSS yang diolah, 2018.

Output yang dihasilkan nilai alpha cronbach pada variabel kompensasi (X) sebesar 0,868, maka hasilnya adalah sangat reliabel artinya penelitian dapat dilanjutkan.

Hasil uji reliabilitas variabel kepuasan kerja (Y) dapat dijelaskan pada tabel 6 sebagai berikut:

Tabel 6. Reliabilitas Variabel Kepuasan Kerja

\begin{tabular}{cc}
\hline \multicolumn{2}{c}{ Reliability Statistics } \\
\hline Cronbach's Alpha & N of Items \\
\hline 0,887 & 10 \\
\hline
\end{tabular}

Sumber: Data SPSS yang diolah, 2018.

Output yang dihasilkan nilai alpha cronbach pada variabel kepuasan kerja (Y) sebesar 0,887, maka hasilnya adalah sangat reliabel artinya penelitian dapat dilanjutkan.

\subsection{Uji Koefisien Korelasi}

Berikut perhitungan uji koefisen korelasi dengan menggunakan SPSS:

\begin{tabular}{|c|c|c|c|}
\hline \multicolumn{4}{|c|}{$\begin{array}{l}\text { Tabel 7. Uji Koefisien Korelasi } \\
\text { Correlations }\end{array}$} \\
\hline & & $\begin{array}{l}\text { Kompen } \\
\text { sasi }\end{array}$ & $\begin{array}{c}\text { Kepuasa } \\
\text { n Kerja }\end{array}$ \\
\hline Kompens & $\begin{array}{l}\text { Pearson } \\
\text { Correlation }\end{array}$ & 1 &, $723^{* *}$ \\
\hline asi & $\begin{array}{l}\text { Sig. (2-tailed) } \\
\mathrm{N}\end{array}$ & 35 & $\begin{array}{r}, 000 \\
35\end{array}$ \\
\hline Kepua & $\begin{array}{l}\text { Pearson } \\
\text { Correlation }\end{array}$ &, $723^{* *}$ & 1 \\
\hline san Kerja & $\begin{array}{l}\text { Sig. (2-tailed) } \\
\mathrm{N}\end{array}$ & $\begin{array}{r}, 000 \\
35 \\
\end{array}$ & 35 \\
\hline
\end{tabular}

Sumber: Data SPSS yang diolah, 2018

Berdasarkan tabel 7 output yang didapatkan signifikan sebesar $0,00<0,05$, maka $\mathrm{H}_{\mathrm{o}}$ ditolak dan $\mathrm{H}_{1}$ diterima. Dapat disimpulkan bahwa ada hubungan signifikan antara kompensasi terhadap kepuasan kerja. Adapun koefisien korelasi dapat diketahui bahwa nilai $\mathrm{R}$ sebesar 0,723 dapat diartikan bahwa kompensasi dan kepuasan kerja memiliki hubungan yang kuat sebab berada pada selang korelasi 0,600 0,799, dan searah karena bernilai positif. Dalam hal ini artinya jika kompensasi yang diberikan kepada pegawai mengalami kenaikan maka kepuasan kerja juga naik. Hubungan yang kuat ini disebabkan adanya kepuasan kerja dari kompensasi yang telah diterima pegawai saat ini. Peningkatan kompensasi dapat meningkatkan kepuasan kerja bagi pegawai bagian SDM \& Umum PT Kereta Api Indonesia (Persero) Daerah Operasi 1 Jakarta sehingga menyebabkan perusahaan harus terus memberikan perhatian terhadap kepuasan kerja. Perusahaan harus berupaya mempertahankan dan meningkatkan kompensasi yang diberikan dengan bijak dan tentunya disesuaikan dengan harapan dari pegawai sehingga kepuasan kerja pegawai tetap terjaga dan terus meningkat.

\subsection{Uji Koefisien Determinasi}

Berikut perhitungan koefisien determinasi menggunakan SPSS:

Tabel 8. Uji Model Summary

Model Summary

\begin{tabular}{|c|c|c|c|c|}
\hline Model & $\mathrm{R}$ & $\begin{array}{c}\mathrm{R} \\
\text { Square }\end{array}$ & $\begin{array}{c}\text { Adjusted R } \\
\text { Square }\end{array}$ & $\begin{array}{l}\text { Std. Error of } \\
\text { the Estimate }\end{array}$ \\
\hline 1 &, $723^{\mathrm{a}}$ & ,523 & 509, & 3,409 \\
\hline
\end{tabular}

a. Predictors: (Constant), Kompensasi

Sumber: Data SPSS yang diolah, 2018

Berdasarkan tabel 8 model summary dapat diketahui bahwa nilai $\mathrm{R}$ Square sebesar 0,523, artinya kontribusi kompensasi terhadap kepuasan kerja pegawai bagian SDM \& Umum pada PT Kereta Api Indonesia (Persero) Daerah Operasi 1 Jakarta sebesar $52,3 \%$ dipengaruhi oleh kompensasi, sisanya yaitu $47,7 \%$ dipengaruhi oleh faktor lain diluar penelitian seperti faktor pekerjaan, kepemimpinan, rekan kerja, dan kondisi kerja.

\subsection{Uji Persamaan Regresi}

Perhitungan uji persamaan regresi menggunakan SPSS adalah:

Tabel 9. Tabel Koefisien

Coefficients $^{\mathrm{a}}$

\begin{tabular}{|c|c|c|c|c|c|}
\hline \multirow[b]{2}{*}{ Model } & \multicolumn{2}{|c|}{$\begin{array}{c}\text { Unstandardized } \\
\text { Coefficients }\end{array}$} & \multirow{2}{*}{$\begin{array}{c}\begin{array}{c}\text { Standardized } \\
\text { Coefficients }\end{array} \\
\text { Beta }\end{array}$} & \multirow[b]{2}{*}{$\mathrm{t}$} & \multirow[b]{2}{*}{ Sig. } \\
\hline & B & $\begin{array}{l}\text { Std. } \\
\text { Error }\end{array}$ & & & \\
\hline $\begin{array}{l}1 \text { (Cons } \\
\operatorname{tant})\end{array}$ & 7,112 & 5,391 & & 1,319 & ,196 \\
\hline $\begin{array}{l}\text { Kom } \\
\text { pensa } \\
\text { si }\end{array}$ & ,809 & ,134 & ,723 & 6,018 & ,000 \\
\hline
\end{tabular}

a. Dependent Variable: Kepuasan Kerja

Sumber: Data SPSS yang diolah, 2018 
Berdasarkan tabel 9 uji persamaan regresi tingkat signifikan sebesar $0,000<0,05$ maka $\mathrm{H}_{0}$ ditolak dan $\mathrm{H}_{1}$ diterima, kesimpulannya adalah persamaan regresi signifikan. Jadi, terdapat pengaruh signifikan antara kompensasi terhadap kepuasan kerja pegawai bagian SDM \& Umum pada PT Kereta Api Indonesia (Persero) Daerah Operasi 1 Jakarta.

Pada tabel Coeficients kolom B diketahui bahwa Constant adalah 7,112 sedangkan kompensasi adalah 0,809 , sehingga persamaan regresinya dapat ditulis, sebagai berikut:

$\mathrm{Y}=\mathrm{a}+\mathrm{bX}$

$\mathrm{Y}=7,112+0,809 \mathrm{X}$

Keterangan:

$\mathrm{Y}=$ Kepuasan kerja

$\mathrm{X}=$ Kompensasi

Konstanta memiliki nilai sebesar 7,112. Hal ini berarti, jika variabel kompensasi bernilai nol (0), maka nilai kepuasan kerja bernilai positif yaitu 7,112. Koefisien regresi kompensasi memiliki nilai koefisien sebesar 0,809 yang berarti jika setiap kenaikan $1 \%$ atau 1 kompensasi, maka akan meningkatkan nilai kepuasan kerja sebesar 0,809. Koefisen bernilai positif artinya kompensasi memiliki pengaruh yang positif terhadap kepuasan kerja, semakin naik kompensasi akan menyebabkan semakin meningkatnya kepuasan kerja pegawai bagian SDM \& Umum pada PT Kereta Api Indonesia (Persero) Daerah Operasi 1 Jakarta.

Berdasarkan penelitian ini kompensasi berpengaruh signifikan dan positif terhadap kepuasan kerja pegawai bagian SDM \& umum PT Kereta Api Indonesia (Persero) Daerah Operasi 1 Jakarta. Dengan adanya kompensasi yang diberikan sesuai dengan keinginan pegawai baik yang berbentuk kompensasi finansial maupun kompensasi non finansial maka akan muncul kepuasan kerja pada pegawai. Oleh karena itu kompensasi merupakan variabel yang penting untuk diperhatikan perusahaan dalam memprediksi kepuasan kerja. penelitian ini sesuai dengan penelitian yang dilakukan oleh(Akmal \& Tamini, 2015), (Purnamasari, 2013), dan (Retnoningsih et al., 2016) yang menunjukkan ada pengaruh kompensasi terhadap kinerja. Penelitian ini mendukung teori yang dikemukakan Hasibuan dalam (Akmal \& Tamini, 2015) yang menyatakan bahwa salah satu tujuan pemberian kompensasi adalah sebagai kepuasan kerja. Penelitian ini juga sesuai dengan teori Mangkunegara dalam (Retnoningsih et al., 2016) yang mengemukakan kompensasi berpengaruh terhadap kepuasan kerja.

\section{IV.KESIMPULAN}

Berdasarkan pembahasan dalam penelitian dapat diambil kesimpulan sebagai berikut:

1. Terdapat hubungan antara kompensasi terhadap kepuasan kerja. Koefisien korelasi sebesar 0,723 yang berarti terdapat hubungan yang kuat antara kompensasi dan kepuasan kerja pegawai bagian SDM \& Umum pada PT Kereta Api Indonesia (Persero) Daerah Operasi 1 Jakarta dan pola hubungannya yang positif. Dalam hal ini artinya jika kompensasi naik maka kepuasan kerja juga naik. Hubungan yang kuat disebabkan adanya kepuasan kerja dari kompensasi yang diterima saat ini oleh pegawai.

2. Koefisien determinasi sebesar 0,523 artinya $52,3 \%$ kepuasan kerja dipengaruhi oleh kompensasi dan sisanya 47,7\% dipengaruhi oleh faktor lain diluar penelitian. Untuk itu perlu penelitian lebih lanjut dengan varabel lain yang dapat mempengaruhi kepuasan kerja pegawai bagian SDM \& Umum pada PT Kereta Api Indonesia (Persero) Daerah Operasi 1 Jakarta.

3. Perhitungan persamaan regresi menunjukkan bahwa ada pengaruh signifikan dan positif atau searah antara kompensasi terhadap kepuasan kerja pegawai bagian SDM \& Umum pada PT Kereta Api Indonesia (Persero) Daerah Operasi 1 Jakarta. Untuk itu perusahaan harus terus memiliki perhatian yang lebih, konsisten, dan bijak dalam upaya mempertahankan dan terus meningkatkan kompensasi baik kompensasi finansial maupun kompenasi non finansial secara seimbang sehingga diharapkan kepuasan kerja pegawai juga terus meningkat.

\section{REFERENSI}

Akmal, A., \& Tamini, I. (2015). Pengaruh Kompensasi Terhadap Kepuasan Kerja Karyawan Gayamakmur Mobil Medan. Jurnal Bisnis Administrasi, 04(2), 59-68.

Badriyah, M. (2015). Manajemen Sumber Daya Manusia. Bandung: Pustaka Setia.

Chintya, E. (2018). Pengaruh Kompensasi Dan Lingkungan Kerja Non Fisik Terhadap Prestasi Kerja Karyawan Pada PT. AIA Financial Malang. AGORA, 6(1), 1-6.

Hartatik, I. P. (2014). Buku Praktis Mengembangkan SDM. Yogyakarta: Laksana.

Mangkunegara, A. A. A. P. (2015). Manajemen Sumber Daya Manusia Perusahaan. Bandung: Remaja Rosdakarya.

Mulyadi. (2015). Manajemen Sumber Daya Manusia (MSDM). Bogor: In Media.

Priansa, D. J. (2017). Manajemen Kinerja kepegawaian dalam Pengelolaan SDM Perusahaan. Bandung: Pustaka Setia.

Purnamasari, I. (2013). Pengaruh Kompensasi Terhadap Kepuasan Kerja Pegawai Pada PT. Eliza Parahyangan Sub Cabang Garut. Jurnal Pembangunan Dan Kebijakan Publik, 04(01), 12-19.

Retnoningsih, T., Sunuharjo, B. S., \& Ruhana, I. (2016). Pengaruh Kompensasi Terhadap Kepuasan Kerja Dan Kinerja Karyawan. Jurnal Administrasi Bisnis (JAB), 35(2), 1-7. 
Safrudi, I. (2015). Pengaruh Hubungan Interpersonal Dan Gaya Kepemimpinan Terhadap Kepuasan Kerja Pegawai (Studi Kasus: Rumah Sakit Umum Kota Tangerang Selatan). Widya Cipta, VII(2), 176-184.

Subariyanti, H. (2017). Hubungan Motivasi Kerja dan Kepuasan Kerja Terhadap Kinerja
Karyawan PTLR Batan. Ecodemica, 1(2), 224232.

Sugiyono. (2016). Metode Penelitian Kuantitatif, Kualitatif, dan $R \& D$. Bandung: Alfabeta.

Sujarweni, V. W. (2015). SPSS untuk Penelitian. Yogyakarta: Pustaka Baru Press. 